\title{
PURCHASE BY AN ENGLISH COMPANY OF ITS OWN SHARES
}

IRVING J. LEVY

Deploring the logic and the policy of the law prevailing in most American states, Professor Garrard Glenn ventures that:

“. . . it may not be too much to hope that the doctrine relating to treasury stock is in for a revision . . . (and that) possibly someone may deem it worth while to look at the admirable model which has been provided in the place where once sprung the common law, and where legislation of good sort is to be found, modern as well as ancient." 1

It is therefore proposed that before studying the "pathological" specimens of law relating to treasury stock in this country, an examination be made of the "admirable model" presented by the law of England. In considering the problems arising out of the purchase by a company of its own shares, it will perhaps not be unprofitable to review briefly the historical development of the relevant English law.

There will be no problems arising out of the purchase by a company of its own shares or a reduction in its capital stock until the concept of capital as a permanent fund to be kept intact develops. No such notion arose in England until the seventeenth century, at least. ${ }^{2}$ The early issues of shares in the East India Company were temporary and terminable at the end of each particular business venture. " "Shares" were regarded as parts of the enterprise. In cases of temporary issues, as parts of the particular

${ }^{2}$ Glenn, Treasury Stock (1929) I5 VA. L. Rev. 625, 642.

28 Holdsworth, History of English Law (3d ed. Ig22) 216. Payment of dividends out of capital was quite usual. I Scotr, Constiturion AND Finance of ENguish, Scottish aNd IrISH Joint Stock Companies to i720 (I910) 60.

s 8 HOLDswortr, op. cit. supra note 2, at 206. The fact that most early corporations were "municipal" corporations probably accounts for the late emergence of modern business corporation problems. 
joint adventure; where permanent, as fractional parts of the several ventures on which the company might embark. And it was not until ${ }^{6} 657$ that permanent joint stock was conceived and used. $^{4}$ Modern notions of shares of stock as financial units were non-existent, and there were no provisions for reducing or increasing the number of shares. The means of raising additional capital was by increasing the contributions of the holders of the original issue of shares-a system of "leviations" or calls. ${ }^{5}$ The practice calls to mind a present day corporation, with, say, an unalterable number of assessable non-par shares.

The development of modern ideas of shares of stock, and for that matter of corporation principles generally, is more to be found in the history of joint stock companies than in that of corporations proper. When a charter from the Crown or a special act of Parliament was a difficult and expensive thing to obtain, the joint stock company proved a convenient organization for carrying on commercial enterprises in which a large number wished to participate. And so they became numerous. Although referred to as "large partnerships" and developed out of the partnership forms, they more closely resembled the corporation. Lacking the corporate advantage of limited liability of the members, they were also without the partnership handicaps of non-transferability of membership and dissolution on the death of a member. Though held to be choses in action, the shares were, at an early date, recognized as freely transferable. ${ }^{6}$ As far back as the sixteenth century, shares in joint stock companies were frequently sold "outside personal acquaintances and without limiting conditions." 7 The same was true with companies of limited liability. We are told "that the whole nominal capital of the East India Company changed hands once in two years." 8

${ }^{4}$ Ibid.

${ }^{5}$ I Scorr, op. cit. supra note 2 , at 45 . The capitalization of companies was seriously curtailed by the rigidity with which the original number of shares was fixed. In the latter part of the 16th century the crude method of splitting shares into fractional parts was devised for increasing the capital. Generally, the use of calls was resorted to for additional money.

'I Scorr, op. cit. supra note 2, at 442 .

I Ibid.

Ibid. 453 . 
In fact, speculation in shares was rampant in England in the seventeenth century. Stock exchanges were active and most of the present day practices of manipulation and trading in shares were known and employed. ${ }^{9}$ The notorious events which culminated in the rise and crash of the South Sea Company and in a serious panic in I720 brought the belated attention of Parliament to the wild speculation in shares, and brought about an attempt to curb the use of joint stock companies. The so-called Bubble Act of $1720,{ }^{10}$ in true parliamentary fashion, ignored the wholesale political bribery and the rashness of the scheme which caused the debacle, and traced the troubles to the use of the corporate form by joint stock companies without government charters. Obstacles were thrown about the use of such joint stock companies with transferable shares, which feature was to be enjoyed only by corporate societies. But the formation of corporations was in no wise made easier, nor was the manipulation of shares of a corporation proper in any way prevented. The act was directed only against the joint stock company, and its development was hindered to the distinct disadvantage of trade. ${ }^{11}$ But we are told that the attempt to eliminate them altogether was futile ${ }^{12}$ and in $1825^{13}$ the Bubble Act was repealed. Subsequent statutes ${ }^{14}$ in quick succession increased the utility of this form of business organization, by conferring on them other corporate advantages. But incorporation continued to be difficult. In fact the Crown was given the power to attach unlimited liability on the members of corporations by provision in their charters. ${ }^{15}$ Not until 1844

${ }^{\circ} 8$ HoLDSWORTH, op. cit. supra note 2, at 206 et seq.

${ }^{10} 5$ \& 6 GEo. I, c. 18 , § I8 (I7I8).

11 Holdsworth, op. cit. supra note 2 , at 216 et seq.

${ }^{12}$ I Lindley, Companies (6th ed. 1902) 3.

${ }^{23} 6$ GEO. IV, C. 9I (1825).

${ }^{14}$ In 1826 the statute of 7 GEo. IV, c. 46 (1826) permitted joint stock companies to sue or be sued in the name of a public officer. See also I \& 2 VICT. c. IIO, \& I4 (1837) et seq.; 5 VICT. c. 5, \$ 4 (I842).

${ }^{15} 6$ GEO. IV, c. 9I, $\$ 2$ (1825). The limited liability of members of corporations which had charters from the Crown or special acts of Parliament was recognized at an early date; in the case of the former, as early as the I5th century. Only by express legislative enactment could incorporators be made personally liable for debts of the company. $5 \& 6$ W. \& M. c. $20, \S 25$ (I693) provided for individual liability if the corporation borrowed more than 
did Parliament endeavor to facilitate organization in corporate form. In that year a statute ${ }^{16}$ was passed enabling people to obtain a certificate of incorporation without applying either for a royal charter or for a special act of Parliament. Except, it seems, in the case of banks thus formed, the advantage of limited liability attached. ${ }^{17}$ Ten years later this privilege was conferred on all companies organized under the earlier act, if their deeds so provided and their names were followed by the word "Limited." 18

With the passage in I862 of the Companies Act, ${ }^{19}$ corporations in England entered their modern phase. Incorporation became a matter of agreement under government supervision. Its essence lay no longer in grant. Companies could thereafter be formed with or without limited liability of members, and the shares in both were freely transferable.

In view of the fact that, prior to this time, the difficulties attending incorporation as a form of business organization greatly limited its use, it is not surprising to find that most of the development of the law of business organization is to be found in connection with the joint stock company of large and small constituency, formed under elaborate deeds of settlement. And the problems which we are considering first appear in the reports regarding the shares of joint stock companies. Although the instances in which a member would be desirous of withdrawing his interest in a venture and the company anxious to keep it from passing to alien hands would seem likely to have occurred at an early date, yet the problem does not appear to have arisen in the English courts before the last century, and then only with the revival of the free use of joint stock after the repeal of the Bubble

$\mathrm{EI}_{\mathrm{N}} 200,000$; or if the capital was diminished by the payment of dividends so that not enough remained to pay the corporate debts, the members were to be liable to the amount of the dividends received. $8 \& 9$ W. III c. $20, \S 49$ (1696). That the same injustice to creditors might arise from a reduction of capital or from a purchase by a company of its own shares does not seem to have been thought of and was not provided for.

${ }^{18} 7 \& 8$ VICT. c. IIO (I844).

${ }^{17}$ See Henderson v. Royal British Bank, 7 E. \& B. 365 (1857). Cf. Taylor v. Hughes, 2 Jo. \& Lat. 25 ( 1844 ).

${ }^{18}$ I8 \& I9 VICT. c. 133 ( I855).

${ }^{19} 25$ \& 26 VICT. c. 89 (I862). 
Act. ${ }^{20}$ But the fact that the deeds of settlement of many companies ${ }^{21}$ made provision for the purchase of their own shares shows that the practice probably prevailed long before it gave rise to any litigation. The first cases arise under the Winding Up Act of 1842 , and in connection with the liability of members who have parted with their shares to the company and who are sought to be included in the list of contributors to make good the debts of the insolvent company. In a joint stock company in which the members enjoy no limited liability their inclusion in such lists might prove a serious financial liability; in the case of a true corporation their liability would extend to the amount unpaid on the shares and the consideration which they received for the shares from the company.

The first cases lean to the view that if the power to purchase or retire shares is included in the deed of settlement, it will be upheld, and the retiring member will thereafter be free from

${ }^{\infty}$ Prior thereto, instances exist of the forfeiture of shares for failure to respond to "leviations." The problem of calls had become a serious one and the charters of some companies expressly provided for forfeiture. I Scorr, op. cit. supra note 2, at 342 . It is to be observed that forfeiture resembles the purchase by a company of its own shares in this wise: that the capital stock is, to that extent, reduced and the shares forfeited become the company's. The power to forfeit never presents any serious problem because the reduction is attended by no expenditure of assets by the company, but, to the contrary, represents in a sense a decrease in its "liabilities." Only in the case of subsequent insolvency does the question of the liability of members whose shares have been forfeited arise, or where such forfeiture was a device to immunize certain shareholders from liability. See Spackman v. Evans, L. R. 3 H. L. I7I (I868). But that a corporation must have the power to forfeit shares would seem to be clear.

${ }^{21}$ Morgan's Case, I Mac. \& G. 225 (I849). As early as I723 we find the question of a corporation's lien on its own stock arising. The Hudson Bay Company provided in its by-laws that its stock should be liable for debts due the company from its members, and that the company might seize and detain the said stock for debts due. The court upheld the validity of this by-law and ruled that other creditors of a bankrupt shareholder could not get at the stock until the lien of the company was satisfied. Child v. Hudson's Bay Company, 2 P. Wms. 207 (1723) (reargued sub. nom. Gibson v. Hudson's Bay Company, I Strange 645 (I725). By-laws providing for forfeiture of stock for not responding to calls are frequent by this time. In the above case Lord Macclesfield said:

". . . by the same reason that this by-law is objected to, the common by-laws of companies to deduct the calls out of the stocks of members refusing to pay their calls, may be said to be void."

However it was realized that such provisions might be injurious to creditors, and the by-laws were strictly interpreted and held to extend to such claims as could be recovered at law, and not in equity. 
responsibility for the debts of the company. ${ }^{22}$ For, the obligations of the remaining members being unlimited, the integrity of the original capital fund for the benefit of creditors is not regarded as essential. But even this principle is not well settled. Other cases ${ }^{23}$ deny the validity of such provisions and the retiring members are included among the contributors. In the absence of any express power, the same difference of opinion prevailed as to the existence of any such power by implication. ${ }^{24}$ These early cases are not carefully analyzed nor particularly well reasoned. The deeper implications of granting or denying the power are not realized nor considered.

\section{II}

The Companies Act of 1862 , the first "general incorporation statute," upon which the modern corporation law of England rests, made no provision for the reduction of capital stock. It did, however, provide for the purchase of the shares of dissentient members who objected to certain changes which would work, in effect, a dissolution of the company. ${ }^{25}$ This is the first statutory authorization of what amounts to a purchase by a company of its own shares, but there is present in the transaction the supervision of the court whose sanction is necessary for the dissolution. In the following year, the Company Clauses Act ${ }^{26}$ authorized the forfeiture of shares for non-payment of calls or the acceptance of the surrender of shares in certain cases. ${ }^{27}$ In $1867,{ }^{28}$ the gap

22 Grady's Case, I De G., J. \& S. 488 (I863) ; Ex parte Bennett, 18 Beav. 339 (1854); In re The Royal Bank of Australia, 4 De G. \& S. I77 (1850). See Ex parte Daniel, 26 I. J. Ch. 563 (1856).

${ }_{23}$ Morgan's Case, supra note 2I; Stanhope's Case, 3 De G. \& S. I98 (I850) ; Lawe's Case, I De G., M. \& G. $42 I$ (1852). See Munt's Case, 22 Beav. 55 (1856).

24 Daniel's Case supra note 22; Stanhope's Case and Munt's Case, both supra note 23. As to the liability of creditors in case of a purchase, see Evans v. Coventry, 8 De G. M. \& G. 835 (I857).

${ }^{25} 25$ \& 26 VxcT. c. $89, \S I 62$ ( 1862 ).

${ }^{20} 26 \& 27$ VICT. c. II8, $\$ \$ 4,9$ \& Io (I863).

${ }^{27}$ And then apparently only if the articles so provide; Teasdale's Case, L. R. 9 Ch. App. 54 (1873) ; Marshall v. Glamorgan Iron Co., L. R. 7 Eq. 129 (1868), and provided that no money be paid by the company for such surrender or cancellation, though presumably other shares might be issued therefor. Eichbaum v. City of Chicago, [I89I] 3 Ch. 459; Rowell v. John Rowell \& Sons, [1912] 2 Ch. 609 . But see the judgment of Stirling and Cozens-Hardy, L. JJ., 
was filled by providing for the direct reduction of the capital by a special resolution followed by the approval of the court. The reduction is to be strictly supervised, creditors are to be listed and notified and are entitled to object and be paid; in the case of contingent liabilities, the court may dispense with payment or waiver by requiring security for the ultimate satisfaction of the debts; future creditors are to be notified of the reduction in the capital by the company adding to its name, "and reduced," for a time.

Thereafter, the English courts had to face a new problem relative to a company purchasing its shares. Reduction of capital was provided for. Purchasing shares indirectly effected such a reduction but there was no statutory authorization therefor. Unless such purchase were for the retirement of the shares and the reduction of the capital, it would be for a resale and as such would constitute a trafficking in shares. If the memorandum of association did not authorize this as one of the objects of the company, the purchase was ultra vires, void and incapable of ratification. ${ }^{29}$ If the memorandum or articles did authorize such an object, the courts had to decide whether it was a legitimate one. When the. case came squarely before the court, the purchase was disallowed.

In Hope v. The International Financial Society, Ltd., ${ }^{30}$ the situation presented was that: at an extraordinary general meeting, the board of directors were authorized to purchase shares from willing shareholders to a total not exceeding 100,000 (out of I 50,000 outstanding), which were not to be reissued without the authority of a general meeting. Plaintiff, a small shareholder and creditor of the company, enjoined the directors from acting on the resolution. The basis for the injunction given by James, L. J., on appeal was that: ${ }^{31}$

in Bellerby v. Rowland, [1902] 2 Ch. 14, which casts doubt on that proposition. The exchange of fully-paid stock for the surrender of shares not fully paid would seem to be clearly objectionable.

${ }^{23} 30$ \& 3I VICT. c. I3I-I39 (I867). (1875).

${ }^{29}$ Ashbury Railway Carriage \& Iron Co., Ltd., v. Riche, L. R. 7 H. L. 653

${ }^{30} 46$ L. J. Ch. 200 ( 1877 ).

${ }^{31} \mathrm{He}$ retracted his dictum in Teasdale's Case, supra note 27, where he was reported to have said: "There is no doubt that a company may give itself power to purchase its own shares, to take surrender of shares and to cancel certificates of shares. 
"Either this is a purchase of shares in the sense of trafficking in shares, which is a business not authorized by the memorandum of association, or it is an extinguishment of the shares and therefore a reduction of the capital. ${ }^{32}$ If the former, it is ultra vires; if the latter, it is invalid because the statutory method has not been followed."

After what seemed to have been a recession ${ }^{33}$ from the view in the Hope case, the House of Lords, in the carefully considered and well-reasoned case of Trevor $v$. Whitzorth, ${ }^{34}$ settled the English law on the subject. The company's object was manufacturing flannel. Its articles authorized the company to purchase its own shares, but this was not listed as an object in the memorandum. The company had gone into bankruptcy, and Whitworth's executors sued the liquidator of the company for the balance due for shares sold to the company. The claim was not allowed.

The dilemma posited by James, L. J., in the Hope case was regarded as inescapable by the Law Lords. Only by the method prescribed in the Acts of 1867 and $I 877$ could the capital be

${ }^{32}$ At page 203 .

${ }^{33}$ In re Dronfield Silkstone Coal Co., Ltd., I7 Ch. D. 76, 50 L. J. Ch. 387 (1880): The company was formed to conduct a coal business and "to do all things conducive" to attaining that object. The articles permitted the directors to purchase its own shares for the company, but there was no such provision in the memorandum. In 1872 the directors purchased the shares of one Ward who was dissatisfied with the way things were being run, and the shares were then registered in the company's name; the transaction was made in good faith and ratified by the stockholders. In I879 the company was ordered wound up and the creditors sought to have Ward included among the contributories. Jessel, $M$. R., held the purchase invalid and ordered Ward included. The Court of Appeal reversed the decision.

James, L. J., who delivered the apinion in the Hope Case, found no difficulty in relieving the shareholder of all further liability, because he had ceased to be a shareholder more than twelve months before the winding up. And a "creditor. qua creditor" had only the right to go after shareholders who had transferred their shares within that time. The company, having ratified the purchase, could no longer question it, and it was thought, therefore, that the transaction was invulnerable. Cotton, L. J., said there was no "trafficking in shares" because the purchase was to rid the company of a troublesome member. It was analogous to a forfeiture and was not such a reduction in capital as required the statutory procedure.

The case was reluctantly followed by the courts as a binding precedent, but the reasoning and the result were disapproved of even before Trevor $v$. Whitworth, infra. In re Balgooley Distillery Company, L. R. I7 Ir. 239 (1886), a transfer of shares to the company in exchange for an overstock of whiskey was upheld on the basis of the Dronfield case, but the Judges expressed their disapproval of Jessel's decision in that case. See also Guiness v. Land Corporation of Ireland, 22 Ch. D. 349 (I882).

${ }^{34}$ I2 App. Cas. 409 (1887). 
reduced. Only such objects as the memorandum listed as legitimate spheres of operation could be prosecuted, and the provision for other powers in the articles was ineffective. The germ of the "trust fund" theory was here fully developed. Capital was thereafter regarded as a fund to be kept intact for creditors for the satisfaction of their claims. Of course, that fund might become impaired through losses in the regular course of business, but that is a risk which creditors must take. But, "they have a right to rely, and were intended by the Legislature to have a right to rely, on the capital remaining undiminished by any expenditures outside these limits, or by the return of any part of it to the shareholders." ${ }^{35}$ True, it may be necessary sometimes to reduce the capital, and the statute allows it, but "the stringent precautions to prevent the reduction of the capital of a limited company, without due notice and judicial sanction would be idle if the company might purchase its own shares wholesale, and so effect the desired result."

Lord Watson was troubled by the theoretical difficulty of having a company "become a member of itself." "It cannot be registered as a shareholder to the effect of becoming debtor to itself for calls, or of being placed on the list of contributories in its own liquidation. . . ."36 Lord Macnaghten saw other objections to entrusting companies with such power. It developed in $\mathrm{Re}$ Dronfield Silkstone Coal $\mathrm{Co}^{37}$ that such procedure was employed to buy out undesirable shareholders:

"Who are the shareholders whose continuance in a company the company or its executives consider undesirable? Why, shareholders who quarrel with the policy of the board, and wish to turn the directors out; shareholders who ask questions which it may not be convenient to answer; shareholders who want information which the directors think it prudent to withhold. Can it be contended that when the policy of directors is assailed they may spend the capital of

\$Ibid. 4I6. (Opinion of Lord Herschell.)

${ }^{36}$ Ibid. 424. In the Dronfield case, supra note 33 , Jessel, M. R., said: "... the purview of the whole of the Act [Companies Act of I862], when you look at the sections relating to the winding up, the mode of winding up, and the mode of enforcing contributions, is utterly inconsistent with the notion that a company can be registered as a member of itself." The Court of Appeal, in reversing Jessel, did not see fit to answer this propounded theoretical difficulty.

${ }^{\text {st }}$ Supra note 33. 
the company in keeping themselves in power, or in purchasing the retirement of inquisitive and troublesome critics?"

Clearly not, he thinks. Further, even if the power to purchase its own shares were found in the memorandum of association, it would necessarily be void, says Lord Macnaghten. If it were the only object of the company, it would clearly be illegal under the Companies Act, for no company can be formed for the sole purpose of trading in its own shares. "Does the purpose of the association become lawful if legitimate objects are combined with an object which is not legitimate?" he asked. The question, it seems, is merely rhetorical. ${ }^{38}$

The rule is thus established in England. ${ }^{39}$ A limited company can only reduce its capital by judicial proceeding in the statutory manner. A shareholder can only rid himself of further liability on his shares by payment in full or by a transfer to another. The London Stock Exchange recognizes and approves the rule by prescribing that companies which seek a quotation for their shares on the Exchange must in their articles prohibit the purchase of their own shares. ${ }^{40}$

This would seem to answer that line of American cases which holds that the power to purchase its own stock is implicit in the power generally given in the statutes or charter to corporations to "purchase and hold real or personal. : ." See Berger v. U. S. Steel Co., 63 N. J. Eq. 809, 53 Atl. 68 (I902). It is probably true that a company in England will not be permitted to purchase shares of a company which is a shareholder in the purchasing company See In re Thomas [I916] 2 Ch. 33I. This may also be an implication of the new section, 45, in the 1929 Company Act, infra note 62 .

$\approx$ The law in Germany is quite similar. THE Commercral CODE, §226 (Schuster translation, I9II) provides that: "A share company may not, in the ordinary course of business, either acquire its own shares or take them as security, except in the execution of a commission to purchase them for a third party." However, the status of treasury stock in Germany is not the same as it is in Anglo-American law. Thus, the company can exercise the rights of a shareholder in respect to such shares as it holds; except that it cannot exercise the right of pre-emption (Bezigrecht ausiiben) since it may not subscribe for its own shares.

In France, by amending its articles of association, a company may decide which of its members should withdraw. This is analogous to a purchase. But the member remains liable for the company's debts for a time. Law of July 24, I867, \&52. 21 Com MERctal LAWS OF THE WORID 197, et seq. However, the French Trading association with variable capital is quite different from our corporations, and in evaluating these provisions the same criteria cannot be used.

${ }^{20}$ Rules of the London Stock Exchange of March 23, 1921, rules I5I \& 152, $\mathrm{B}(\mathrm{I})$, quoted in I PaLMer, CoMpany Precenents (12th ed. rg08) 255. 
The arguments in this country for permitting corporations to purchase their own shares, at least out of surplus, are usually as follows: First, that such power may be of great advantage to a corporation in enabling it to remove undesirable shareholders and replace them with desirable ones. ${ }^{41}$ The answer to this argument was forcefully put by Lord Macnaghten, supra. If this be a valid purpose in some instances, the English courts would say that the remaining members should make the purchase, thereby keeping the original contributed capital and financial set-up unchanged. Secondly, to entice parties, otherwise reluctant, to purchase stock by contracts to repurchase the shares at their option. ${ }^{\mathbf{4 2}}$ This feature is of questionable value. It gives shareholders the opportunity of retiring from failing ventures, and in so far as creditors are likely to be unaware of the existence of such strings to stock subscriptions, it seems somewhat fraudulent. Other shareholders likewise may have cause to object because their absolute subscriptions may have been made thinking the others have also contributed their sums to the business without reservations. The United States Supreme Court ${ }^{43}$ has questioned the validity. of the practice. Thirdly, it is argued that the power permits companies to make provision for the holding of stock as an incident of employment. The practice of employee-shareholders is not unknown in England; an option in the remaining shareholders to repurchase the employee's stock upon the termination of his employment accomplishes the same purpose, and is not an unlaw ful restraint on alienation. ${ }^{44}$ Reissue of shares to incoming employees may be made from these shares purchased from retiring employees or from authorized but unissued shares. Further, there would probably be no objection in England to the practice of compromising an otherwise uncollectible debt from a member by accepting the surrender of his shares ${ }^{45}$ for his liability to cred-

¿1 Copper Belle Mining Co. v. Costello, II Ariz. 334, 95 Pac. 94 (I908); Cole v. Cole Realty Co., I69 Mich. 347, I35 N. W. 329 (I9I2).

"See note (I928) 4 I HARV. L. REv. 657; Schulte v. Boulevard Land Co., 164 Cal. 464 , I29 Pac. 582 (1913).

${ }^{43}$ Burke v. Smith, I6 Wall. 390 (U. S. I872).

* Bargate v. Shortridge, 5 H. L. Cas. 297 (I85I); Ex parte Penney, I. R. 8 Ch. App. 446 ( 1872 ).

is Lord Herschell in Trevor v. Whitworth, supra note 34, at 4I8; Cf. Hopkinson v. Mortimer, Harley \& Co. [rg17] I Ch. 646. 
itors would continue, ${ }^{46}$ for what it is worth, and since he is by hypothesis, financially irresponsible, his release from calls would be no loss to anyone. The recognized power in England to accept surrenders, to forfeit shares, ${ }^{47}$ and to take shares by gift or devise refutes the other arguments for permitting such purchases.

The English courts have decided that the rule applicable to companies in which the members enjoy limited liability does not apply to "unlimited companies." As to such companies, there is no prohibition against the purchase of their own shares. Members may retire if the articles or memorandum so provide and be relieved from liability to creditors in the absence of fraud or any deliberate scheme to escape liability. In In Re Borough Commercial and Building Society ${ }^{48}$ the court held that the rule of Trevor v. Whitworth did not apply to such companies. There is nothing in the Companies Acts prohibiting an unlimited company from purchasing its own shares. It is argued that the nature of a company in which all its members are liable for all the company's debts does not require that any capital fund be kept intact:

"By the very force of the terms, it is plain that in the case of an unlimited company the creditors know that there is no fixed capital, and, therefore they have no right to complain, if I may use the term, of a reduction of that which has never been fixed in any way." 49

There could be no reliance, it is thought, because by examining the articles, creditors would find that a member could withdraw by doing certain acts. ${ }^{50}$ In the actual case, in order to borrow money from the company, the applicant was required to take up a number of shares. Upon paying his debt, he ceased to be a member, and this court held that he was not liable for the com-

¿ Companies Act, rg29, Schedule A, Clause 27.

"Ibid. \& I08, subsection 3; also Table A, clauses 23 et seq.

28 [1893] 2 Ch. 242.

At page 255 .

${ }^{\infty}$ The Judge suggests that there may very well be a different rule where the articles give no such power of withdrawal. This feature would seem to be important only if the reason for the rule is the constructive notice to creditors, and not the unlimited liability of all remaining members. 
pany's debts on a winding-up. ${ }^{51}$ The court distinguished ${ }^{52}$ a company of limited liability from one of unlimited, for in the case of the former the creditors presumably rely on the integrity of the capital, and the Companies Act prescribes the method for the reduction thereof; Trevor $v$. Whitworth was approved as a rule for cases involving such companies.

\section{III}

Since the later English courts have repeatedly expressed their satisfaction with the rule of Trevor $v$. Whitworth, and Parliament has by its most recent Corporation Act of 1929 given it statutory approval, it remains to be seen how its implications have been applied in fact situations which vary from the norm, but which present the same basic problems as an outright purchase of shares.

Since 1862 , in the case of the amalgamation or reconstruction of companies, dissentient members have been given the right to an appraisal and payment of the value of their shares. ${ }^{53}$ To the extent that there are dissentients whose shares are to be bought up, this section authorizes indirectly the purchase of shares by a company. This apparent exception to the prohibition in Trevor $v$. Whitworth has never caused any difficulties, because the situations arise only in cases where the company is being wound up and the rights of creditors are taken care of. Wherever the rights of creditors conflict with this statutory remedy for dissenting members, the former prevail, and the entire proceedings are under court supervision from the time application is made for approval of the reconstruction scheme, ${ }^{54}$ so that the apparent conflict between the

It is not clear from the case whether the debts of the company accrued before or after the retirement of the defendant. No distinction was made in the opinion, and probably in the actual case the debts were of both periods. It is not suggested by the opinion that it might make a difference in the result.

$E^{2}$ Since the passage of the Companies Act in I862, the English courts carefully differentiate between a true corporation and a joint stock company lacking the limited liability feature. Prior thereto the essential difference between these two forms of business organization was not clearly perceived, and the need for different rules of law not fully appreciated.

${ }^{\infty}$ Op. cit. supra note $46, \S 234$. See I. J. Levy, Rights of Dissenting Shareholders to Appraisal and Payment (1930) I5 CORN. L. Q. 420 passim.

st A dissenter, moreover, will still remain liable to creditors of the company after he has cashed in his shares. Part's Case, L. R. 10 Eq. 622 (1870). Except if the creditors have assented to look solely to the transferee company for the satisfaction of its claims. Taurine Co., Anning and Cobbs' Case (1878) $3^{8}$ L. T. R. 53 . 
rights of dissenters and the prohibition against the purchase of a company's own shares; presents no real difficulties. ${ }^{\mathbf{5 5}}$

A surrender of shares not fully paid in, on the other hand, may bring about the same undesirable situation as an outright purchase. A surrender which involved the return of any money to the shareholder, would be as objectionable as, if it could be distinguished from, an outright purchase. Such a transaction would not be permitted, and even where the surrender involves no return of money to the retiring member, objections are apparent. Though, to the extent of the money which has already been paid on the shares and which is forfeited by the surrender, the surrender reduces the obligations of the company to its members and makes the financial position of the remaining shareholders that much more desirable in respect of their share in the profits and assets, the creditors are in no way benefited, but may easily be prejudiced. For, in any event, the creditors' right to payment is prior to that of the shareholders in the event of a dissolution; and; in so far as such surrenders, if sustained, would release the member from calls up to the amount unpaid, the position of creditors is impaired.

In Bellerby v. Rowrland, Etc. Co. ${ }^{56}$ the company suffered a loss and the plaintiffs, directors, to make good the loss (though not in fact liable), surrendered their shares to the company. The shares were of the par value of $f I I$, of which $\mathfrak{E}$ ro had been paid. Thereafter the company prospered and the plaintiffs sued for the return of their shares and recovered judgment on the strength of Trevor $v$. Whitworth. The transfer was held to be ineffective because it meant the release of the plaintiffs from calls, and the situation was regarded as analogous to a purchase. ${ }^{57}$

cs It is to be noted that this statutory right of dissenters runs counter to one of the reasons for the Trevor $v$. Whitworth rule, that the original capital invested should be unimpaired by the withdrawal of any member. But here the company is being dissolved, and in any case the members of companies buy into such an arrangement, as the Companies Act provides therefor.

${ }^{60}[1902] 2 \mathrm{Ch}$. I4.

or It would seem that the decision in the case was unnecessary if its purpose was merely to affirm the Trevor case. For the surrender did not release the plaintiffs from liability for calls. Schedule A, \$27, Companies Act, 1929. Therefore, no one was prejudiced. The decision may have been motivated by the desire on the part of the court to compensate these directors for their, what proved to be, unnecessary generosity. 
But a surrender of fully paid shares would seem to be similar to a gift and unobjectionable. ${ }^{58}$ Though the results of a forfeiture of shares may be similar to those of a surrender, the power to forfeit must be granted to a company to enable it to enforce calls. And, since the forfeiture of shares does not release a member from liability for the unpaid amount, ${ }^{59}$ creditors are not harmed. So also, a voluntary surrender in cases where the statute permits a forfeiture would seem to be permissible, ${ }^{80}$ as the equivalent of forfeiture, and a voluntary gift or bequest of its shares to a company has been upheld in England, the objections to a purchase not being present in such transactions. ${ }^{61}$

Attempts made to evade the rule of Trevor $v$. Whitworth by the indirect purchase of shares through a syndicate financed by the company has been countered by a statutory prohibition in the I929 Companies Act. ${ }^{62}$ A frequent method of circumventing the prohibition had been to employ a syndicate to purchase a majority of the shares in a company, borrowing the money temporarily from a bank on the security of the shares to be purchased. The syndicate then had its nominees appointed directors of the company, and they loaned to the syndicate out of the company's funds enough money to pay the bank. The statute now makes it unlawful:

". . . for a company to give, whether directly or indirectly, and whether by means of a loan, guarantee, the provision of security or otherwise, any financial assistance for the purpose of or in connection with a purchase made or to be made by any person of any shares in the company. . . ."

IV

The illustrations thus far follow along quite consistently with Trevor $v$. Whitworth. But the English law relating to the sources available for dividends and the reduction of capital are strange bedfellows with the prohibitions against the purchase by a company of its own shares. The sanctity of the contributed capital

\footnotetext{
${ }^{68}$ In re Denver Hotel Company, [1893] I Ch. 495.

${ }^{2}$ Op. cit. supra note 46 , Schedule A, \$ 27 .

${ }^{\infty}$ Bellerby v. Rowland, etc., Co., supra note 56 , at 31 .

ar Kirby v. Wilkins, I42 L. T. R. I6 (1930).

es I9 \& $20 \mathrm{GEO}$. V, c. 23 \$ 45 (Ig29).
} 
which Lord Herschell stressed is lost sight of when these analogous problems come before the courts. The possible injury to creditors is momentarily forgotten and the injury which shareholders may suffer is not even perceived.

Since every reduction of capital in England must be brought about under the supervision of the court, ${ }^{63}$ the problems are not the same as in this country, where the reduction is attacked after it has been effected. But this feature has not made the English law any less flexible, for the English courts have displayed considerable liberality in their approval of schemes for reduction. In all cases the rights of creditors are taken care of, for it is a condition precedent to any reduction that their claims be satisfied or secured. The problems which will cause argument are the resulting relations among the shareholders. Lord Macnaghten puts the procedure succinctly:

"Creditors are protected by express provision. Their consent must be procured, or their claims must be satisfied. The public, the shareholders and every class of shareholders, individually and collectively, are protected by the necessary publicity of the proceedings, and by the discretion which is entrusted to the court . . . the safeguards . . . are not inconsiderable. . . ."

The discretion of the court is unlimited. It has jurisdiction to confirm any kind of a reduction, even though it involves a departure from the "legal rights" of the different classes of stock. And the same judges who decided Trevor $v$. Whitworth approved of a reduction which was not made ratably among all the shareholders in British and American Trustee and Finance Co. Ltd. v. Couper. ${ }^{85}$ Lord Macnaghten, who in the former case showed himself quite unenthusiastic about the need for a company to rid

Op. cit. supra note $46, \S 56$ et seq.

as Poole v. National Bank of China, [1907] A. C. 229.

$\infty$ [1894] A. C. 399. In this case the company carried on an investment business holding some shares of American companies. The Board of Directors was advised by an American committee made up of American shareholders. Differences arose between the shareholders on both sides of the Atlantic as to policy, and it was proposed to turn over all the American investments to the American committee, and cancel their shares upon payment to the company of fIr,coo. The House of Lords approved of the transaction. 
itself of objecting members, thought it quite proper for a company to divide the assets and enterprise between two factions through a non-ratable reduction. The altered nature of the resulting venture and the altered status therein of objecting members failed to move the court. "It is for the company, and for the company alone," said Lord Macnaghten, "to judge of the prudence of the course proposed." It is true that he finds that the proposed change is not "unfair or inequitable in the ordinary sense of those words." But neither was any oppressiveness shown in Trevor $v$. Whitworth. There, too, it was sought to rid the company of members who disapproved of the policy of the directors, and yet His Lordship asked in that case:

"Can it be contended that when the policy of directors is assailed they may spend the capital of the company in keeping themselves in power, or in purchasing the retirement of inquisitive and troublesome critics?"

The earlier cases ${ }^{66}$ seem to have decided that a reduction of capital must be an all-round one; that is to say, where capital is to be paid off or to be cancelled as lost or unrepresented by any available assets, or where the liability for unpaid capital is to be reduced or extinguished, the same percentage should be reduced on each share. This ratable reduction would leave each shareholder the same proportionate interest and rights which he had before. Any other scheme would disturb and alter the relative positions of the members. This was applying the rule of Trevor v. Whitworth significantly. For the purchase of shares by a company is injurious, not only to creditors, but it is objectionable also in that it withdraws part of the original capital from the venture and redistributes and changes the relative rights of the remaining members. If, therefore the House of Lords in the Couper case meant to disapprove of Lindley, L. J.'s, observation in Re Denver Hotel Company, ${ }^{67}$ that by reducing its capital a company "cannot prefer one shareholder to another of the same class by buying his

\footnotetext{
${ }^{\infty}$ In re Barrow Haematite Steel Co., [1900] $2 \mathrm{Ch} .846,850$ (Opinion of Cozens-Hardy, J.) ; Union Plate Glass Co., [1889] 2 Ch. D. 513; Credit Assurance and Guarantee Corporation, [1902] 2 Ch. 60r.

or [1893] I Ch. 495 .
} 
shares," then Trevor $v$. Whitworth loses its major significance. It resolves itself into a rule of law which concerns itself only with the interests of creditors. Being satisfied that they are protected by the resort to the necessary statutory method for reduction, the discretion of the court will only be directed to prevent an inequitable price for those shares retired or a fraudulent design. For the House of Lords has also repudiated in Poole v. National Bank of China ${ }^{68}$ the intimation of Buckley, L. J., in Re Anglo-French Exploration Co., ${ }^{68}$ that the capital which is sought to be reduced must have been lost or unrepresented by available assets. The reason for the reduction is in the discretion of the majority of the company. It leaves:

". . . the company to determine the extent, the mode, and the incidence of the reduction and the application or disposition of any capital moneys which the proposed reduction may set free." 70

It is not as if the argument were not presented to the court. Counsel for the shareholder in the Couper case argued that the proposal was bad not merely because it was a purchase of shares, but because it involved dealing with shareholders in different ways. The answer of the court was that mere difference of treatment did not imply of necessity "anything unfair or inequitable in the transaction." It was sufficient, the court thought, if no fraud were shown and the book value of the remaining shares was not immediately hurt. The court failed to see that any reduction of capital for the purpose of retiring some few shares is, without more, unfair to objecting shareholders who should have the right to have the venture continued as originally embarked upon, without a depletion of the capital which was originally contributed for its prosecution. ${ }^{71}$ Nor are dissenters given the right to be paid-out

\footnotetext{
${ }^{63}$ Sispra note 64 .

${ }^{\infty}$ [1902] 2 Ch. 845 .

${ }^{\text {mo }}$ Lord Macnaghten in the Couper case, repeated by him in Poole v. National Bank of China, supra note 64 .

"I In Germany where a company may not purchase its own shares, the almost necessary corollary exists that a reduction of capital must be applicable to all shares, parri passu. Exch. Cas. 25, 258. See note 86, infra.
} 
and withdraw. ${ }^{72}$ They are forced to continue as members of a new enterprise.

A lawyer, considering the case of Burnes v. Pennel, ${ }^{73}$ decided in I849, might have thought that Lord Campbell's far-sighted opinion, which roundly condemned the payment of dividends out of capital, would have settled English dividend law in a way that would have dovetailed neatly with Trevor $v$. Whitworth when that case was decided as it was. Dividends were to be paid only out of profits. Capital was to be reduced under court supervision as the Acts of $1867^{74}$ and $1877^{75}$ provided; any other reduction would be illegal. These are the implications of Burnes $v$. Pennel and the Trevor rule, and were followed until the famous decision in Lee v. Neuchatel Asphalt Co. ${ }^{76}$ That case held that a company owning wasting assets might pay dividends regardless of depletion and that this would not be such a return of capital as was forbidden. The case involved the peculiar situation of a company whose main assets were mines which were meant to be exploited and depleted; but, though not all the remarks made in the opinion were necessary for the decision, it nevertheless opened the way for a whole line of cases which have held that capital losses of whatever nature need not be recouped before dividends are paid, if current earnings are sufficient for that purpose. ${ }^{77}$ The Lee rule has been applied to companies whose assets are not of the wasting kind, but rather of such nature as should be kept intact if the company is to continue operations, and to losses in capital entirely accidental or consisting in depreciation for which sound business policy has ever set up a reserve.

${ }^{72}$ In some American states this remedy is afforded dissenters, because the injustice of forcing them to continue in an altered venture is recognized. See 1. J. Levy, Rights of Dissenting Stockholders to Appraisal and Payment (I930) I5 CORN. L. Q. 420.

${ }^{3} 2$ H. L. Cas. 497 (1849).

730 \& 3 I VICT. c. I3I (I867).

T3 40 \& 4I VICT. c. 26 (I877).

${ }^{70} 4 \mathrm{I} \mathrm{Ch}$. D. I ( 1889 ).

$\pi$ Bolton v. Natal Land Co., [1892] 2 Ch. 245; Verner v. General and Commercial Investment Trust, [1894] 2 Ch. 239; Bosanquet v. St. John del Rey (1897) 77 L. T. 206; Lawrence v. West Somerset Mineral Railroad Co., [1918] 2 Ch. 250. 
The House of Lords did not again have the question before it until I9OI in Dovey v. Cord $_{9}{ }^{78}$ where it was sought to make a director liable for dividends paid to shareholders. The balance sheet treated certain debts as good which were most certainly bad, and it was claimed that thereby a loss in capital had been caused which should have been made up before dividends were paid. The Court of Appeal ${ }^{79}$ held for the defendant, and said that the dividends were properly paid even though the capital had previously been impaired. The House of Lords affirmed the decision on another point, and expressly refused to adopt the view below on the question of the sums available for dividends, several judges showing an inclination to dissent from the view of the Court of Appeal. But the subsequent decisions in the lower courts have shown no tendency to retreat from the series of cases headed by Lee v. Neuchatel, in spite of the adverse criticism which has been levied against them ${ }^{80}$ in England and in the United States and the veiled disapproval of the House of Lords in Dovey v. Cord: There was a distinction made, however, in the Court of Appeal between a loss in "circulating" capital which must be replaced before dividends should be payable out of current earnings, and depletions in "fixed" capital which need not be replaced. The latter is the capital in the form of building, equipment, etc., permanently dedicated to the business, the former the goods and cash intended to be put in circulation to return with an accretion. ${ }^{81}$

So far as the reliance of creditors on the capital fund for the payment of their claims was involved, Trevor $v$. Whitworth made no such classification of capital, nor any distinction between its different forms. Lord Herschell said ${ }^{82}$ the creditors :

". . . have a right to rely and were intended by the Legislature to have a right to rely on the capital remaining undi-

${ }^{78}$ [Igor] A. C. 477.

[I899] 2 Ch. 629.

80 PaIMer, Company LaW (12th ed. I924) 227 et seq.; Note I8 L. Q. Rev. 336; RetTer, Proftts, Dividends and THE LAW (I926); Hatfield, Modern Accounting (2d ed. 1917); Weiner, Theory of Anglo-American Dividend Law (1928) 28 CoL. L. REv. 1046. See Sparger, Profits, Surplus and the Payment of Dividends (1929) 8 N. CAR. L. Rev. I4.

s1 Ammonia Soda Co. v. Chamberlain, [rg18] I Ch. 266; Verner v. General and Commercial Investment Trust, supra note 77.

Supra note 34 , at page $4 \mathrm{I} 4$. 
minished by . . . the return of any part of it to the shareholders."

It is safe to assume that the purchase of its own shares by a company out of "fixed capital" would have been as roundly condemned by the House of Lords as one out of "circulating capital." The evil against which that decision was directed is equally present in both situations. Further on in his opinion, the same judge said:

"The shareholders receive back the moneys subscribed and there passes into their pockets what before existed in the form of cash in the coffers of the company, or of buildings, machinery, or stock available to meet the demands of creditors." 83 (Italics the writer's.)

Both fixed and circulating capital were listed indiscriminately, and the withdrawal of either was considered objectionable. Factually there is no less reliance by creditors on one than on the other; both had to be kept intact from impairment by any non-statutory reduction of capital - at least until the Court of Appeal made an exception in respect to the payment of dividends.

Nor are creditors alone concerned with such a policy of dividend law. Shareholders should have the right to insist on the preservation of all the contributed capital for the prosecution of the venture, except in the case of a legitimate reduction of capital which the statutes authorize and which they are presumed to have made part of their contracts with the company. "Trafficking in shares," against which Trevor $v$. Whitworth was directed, was undesirable not merely because it was ultra vires, but because it resulted in an unauthorized change in the enterprise.

The payment of dividends out of current earnings, when capital losses have been suffered, produces the same result as an outright purchase of shares out of capital. It continues a venture in an altered status, due to normal losses which have not been repaired by the retrenching essential to continuing the business as originally embarked upon. It was the strain of attempting to reconcile their dividend law with the unequivocal decision in the

${ }^{\infty}$ At page ${ }^{\mathrm{I}} 6$. 
Trevor case that brought forth from the Court of Appeal the novel concept of capital which has found little favor.

The passive attitude of Parliament in the face of this confusion is surprising. The careful and elaborate Companies Act of I929 is silent, except as it repeats the generality that "No dividend shall be payable otherwise than out of profits." 84 Though similar provisions in the earlier Acts have failed to aid the courts in determining what were available profits, and the House of Lords has intimated that their findings may well be erroneous, Parliament has thrown no further light on the subject.

In fact, the Act of 1929 has added to the confusion. A new section is introduced giving companies the power, if their articles so provide, to issue preferential shares, which are, or at the option of the company are to be, liable, to be redeemed out of "profits available for dividends," or out of the proceeds of a fresh issue of shares made for the purpose of redeeming the others. ${ }^{85}$ This section is an exception to the prohibition against the purchase of its own shares by a company, for such redemption, whether for retirement or reissue, is in effect a purchase. When made out of surplus profits, the practice would seem to be unobjectionable. The capital fund originally contributed would be unimpaired both for creditors and for continuing the business. Since the articles so provide, there is an element of consent present among the members and they later should not be heard to object. Where the redemption is out of the proceeds of a fresh issue of shares for

\& Table A, § gr.

$\approx \$ 46$. Hitherto the power to issue redeemable preference shares existed only when given by a special act of Parliament. The section further provides that where any such shares are redeemable otherwise than out of the proceeds of a fresh issue, there must be transferred out of profits which would have been available for dividends, a sum equal to the amount applied to redeeming the shares to a reserve fund, to be called "the capital redemption reserve fund." The provisions of the Act relating to the reduction of the share capital are to apply as if the capital redemption reserve fund were paid-up share capital of the company. If redeemable at a premium, the premium must, if the redemption is out of the proceeds of a fresh issue, be provided for out of profits. The balance sheet of companies having such shares must show their existence, the number, and the times when redeemable. The company and officers who violate this section are liable to a fine not exceeding $f 100$.

The care with which the section guards the capital fund from impairment through the use of redeemable shares, suggests that Parliament may disapprove of existing dividend cases. This may also be the meaning of the use of the phrase "profits available for dividends," and not merely "profits" or "sums available for dividends." 
that purpose, there, too, the practice is unassailable. ${ }^{86}$ But suppose there have been capital losses, as in Verner \%. General \& Commercial Investment Trust, ${ }^{87}$ or past losses have been ignored as in Dovey $v$. Cord, ${ }^{88}$ and the redemption is sought to be made out of current earnings. The Court of Appeal has held that such profits are available for dividends, and consequently under the Act they would be applicable for the redemption of shares. The same arguments which militate against the use of such funds for dividends-both from the standpoint of creditors and of remaining shareholders-apply with the same force against their use for redemption. And, just as it is difficult to see how the courts which have approved of Trevor $v$. Whitworth have accepted the Lee v. Neuchatel line of dividend cases, is it equally baffling to find Parliament seemingly approving of both, or at least definitely reaffirming the Trevor rule by statutory enactment and not expressly disapproving of the dividend decisions.

Of course the merit of this new provision in the act depends on the further development of English dividend law. If the series of cases following Lee v. Neuchatel prevails, the use of such funds for redemption of preference shares would make the addition of Sec. 46 of questionable value to English company law. However, the tone of Dovey $v$. Cord indicates that the Court of Appeal view may not in the long run prevail. ${ }^{82}$ Mr. Palmer ${ }^{90}$

${ }^{80}$ In Germany, where the redemption of shares is likewise permitted where the memorandum so provides, it must be done by following the procedure for the reduction of capital except if such redemption is out of surplus-profits; Commercial Code $\$ \S 226,227$. If out of the latter, the practice would be unobjectionable; if through a reduction of capital, there is likewise no cause for complaint. For the articles dealing with reduction of capital call for notice to creditors, payment of or security for their debts, and the charter must provide for a common plan of redemption applicable to all shares, ibid. $\$ 28 \mathrm{~g}$. This is similar to the law in some American states where the reduction or redemption must be rateable. General Investment Company v. American Hide and Leather Co., 98 N. J. Eq. 326, I29 Atl. 244 (1925) ; Berger v. U. S. Steel Corp., supra note 38 .

si Supra note 77.

${ }^{\circledR}$ Sicpra note 78 .

DIt is to be noted though that Lord Davey in that case made some remarks which show that he has accepted the distinction between fixed and circulating capital as having some merit, and that apparently that distinction may have some bearing on the House of Lords' ultimate determination of English dividend law. But see the opinion of Scrutton, L. J., in Ammonia Soda Co. v. Chamberlain, supra note 8I.

Op. cit. note 8o, at $23 \mathrm{r}$ (Palmer). 
anticipates "further developments," when the House of Lords has the issue before it again. It will require considerable repudiation to make English dividend law square with Trevor $v$. Whitworth, with which the courts do not seem to be displeased. In the meantime, we are told,

“. . . notwithstanding the Lee $v$. Neuchatel series of decisions, companies, as a general rule, ascertain their profit on sound business principles, and, acting under the advice of competent auditors, decline to avail themselves of the power, which the principles laid down in the discredited decisions would allow, to inflate profits at the expense of capital."

It is probably true that the law relating to treasury stock in most American states is sorely in need of revision, as Professor Glenn has argued. But this cursory examination should show that we cannot, without reserve, accept the English law as a "model." There are many things we can learn from a study of the English statutes and cases, but they will include the realization of rules to avoid in our revision as well as features to adopt.

${ }^{\text {or }}$ Ibid. 232. 